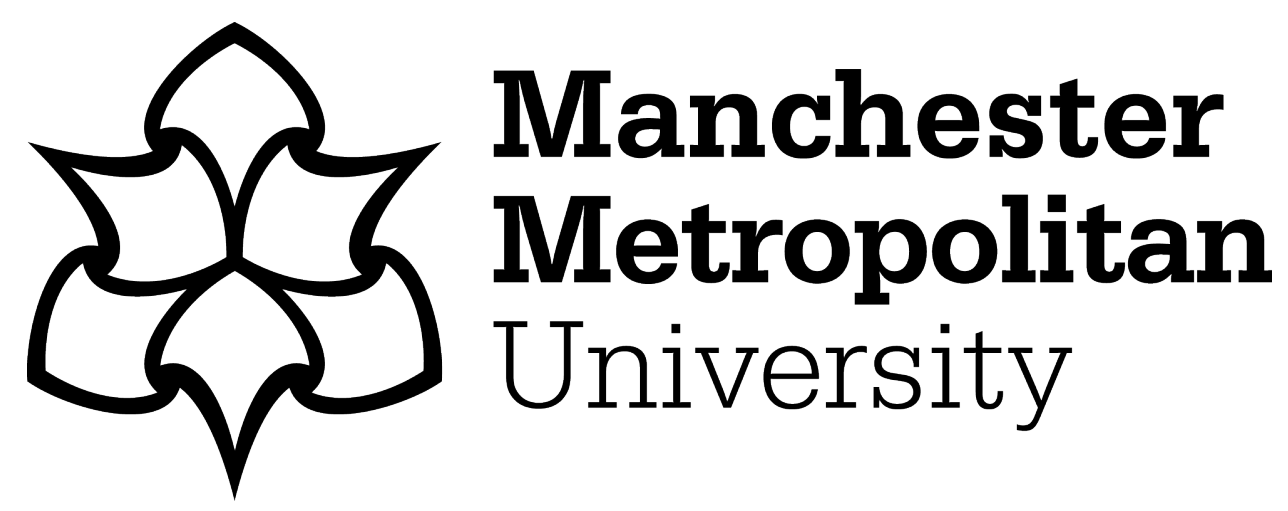

Hurst, SA and Wroe, AJ (2016) Partisan polarization and US foreign policy: Is the centre dead or holding? International Politics, 53. pp. 666-682. ISSN 1740-3898

Downloaded from: https: //e-space.mmu.ac.uk/694/

Version: Accepted Version

Publisher: Springer

DOI: https://doi.org/10.1057/s41311-016-0002-z

Please cite the published version 


\title{
Partisan Polarization and US Foreign Policy: Is the Centre Dead or Holding?
}

\begin{abstract}
Scholars generally agree that most congressional decision-making behaviour has become characterised by partisan polarization. One area to which this consensus does not extend, however, is decision-making on foreign and national security issues. While a majority of scholars believe congressional foreign policy voting is now polarized, others insist that bipartisanship remains the norm. Examining roll-call votes in the House of Representatives from 1970-2012, this paper brings three new elements to bear on the dispute. Using a more comprehensive range of indicators, we re-examine the longitudinal data previously presented by scholars; we add an analysis of the roll-call data for the 2004-13 period, and we utilize a static measure of polarization. Our analysis of the data reveals a cyclical trend of increasing and decreasing polarization and we conclude that it is too simplistic to characterise congressional voting on foreign and national security issues since 1970 as either partisan or bipartisan.
\end{abstract}

\section{Article}

Does partisan polarization threaten to undermine the coherence of US foreign policy? Since 1945 that policy has been based on a liberal internationalist consensus blending cooperative/consensual elements (support for international institutions, foreign assistance and free trade) with coercive ones (defence spending, military superiority and the use of force). This consensus has been sustained by the dominance of centrist politicians in both political parties who recognize the necessity of cooperation and coercion in a successful foreign policy. However, increasing partisan polarization has led to fears that the centre ground may 
be being abandoned, with Democrats backing only the cooperative tools of foreign policy whilst Republicans overwhelmingly favour coercive means. The potential consequences of such a development are the replacement of the liberal-internationalist consensus by a foreign policy characterized by deep swings between cooperative and harder-line policies and/or increasing foreign policy gridlock as the partisan opposition in Congress seeks to block presidential initiatives. Both outcomes would clearly impinge upon the ability of the USA to construct a coherent foreign policy.

Such dire consequences, however, depend upon foreign policy polarization actually existing in the first place. Whereas scholars readily agree that contemporary congressional decision-making on domestic issues has been characterized by increasing partisan polarization, there is no such consensus in relation to decision-making on foreign and national security issues. Some scholars argue that polarization has come to characterize foreign policy making, while others insist that bipartisanship remains the norm. This paper addresses this dispute and seeks to advance our understanding of the nature and extent of foreign policy polarization. Using a more extensive range of longitudinal indicators than has previously been employed, and extending the time period under study to include the whole of George W. Bush's presidency and Barack Obama’s first term, our analysis suggests strongly that the post-1970 period has been characterized by a cyclical trend of increasing and decreasing polarization which challenges both the polarization and bipartisan positions. We also employ additional indicators to measure whether Congress is polarized over foreign policy at specific points in time. These also challenge the established positions. In sum, the simple dichotomy between polarization and non-polarization which characterizes the existing debate does not capture accurately the complexity of contemporary congressional voting on foreign and national security issues. This, in turn, suggests the need to develop better and more complex models if we are to understand the impact of polarization in this sphere. 


\section{DEAD CENTRE OR HOLDING CENTRE?}

Between the 1940s and the 1970s the two dominant American political parties were ideologically incoherent entities, both of which contained liberal and conservative wings. As a consequence, votes in Congress frequently saw two bipartisan coalitions voting against each other. It is generally accepted, however, that since the early 1970 s partisan polarization has been steadily increasing at the level of party elites and within Congress (Fleisher and Bond, 2000; Hetherington, 2001, 2009; Jacobson, 2010; Layman et al, 2006; Levendusky, 2009; McCarty et al, 2006; Poole and Rosenthal, 1984; Sinclair, 2006; Stonecash et al, 2002; Theriault, 2008; Voteview.com, 2012, 2014). ${ }^{1}$ Analysis of DW NOMINATE scores up to the end of the first session of the 113th Congress, for example, demonstrates that the ideological gap between the parties is now greater than at any point since Reconstruction (Voteview.com, 2014).

There remains, however, significant disagreement regarding the extent to which polarization has come to characterize policy-making. In the first instance, there is a broad consensus that in the period between the late 1940s and early 1970s the making of US foreign policy was characterized by low levels of polarization (McClosky et al, 1960; McCormick and Wittkopf, 1990; Meernik, 1993; Prins and Marshall, 2001). Indeed, the extent of bipartisan support for the foreign policies of presidents of both parties in this period led Aaron Wildavsky to articulate his famous 'two presidencies' thesis, in which he claimed that presidents gained congressional support for their policy position 'about 70 percent of the time in defense and foreign policy, compared with 40 percent in the domestic sphere' (Wildavsky, 1966: 8). 
Opinions diverge, however, about the post-1970 period. Most analyses of elite and mass survey data suggest that the foreign policy preferences of Republicans and Democrats have become increasingly distinct over the last four-and-a-half decades (Newman and Siegle, 2010: 352-3; Nincic, 2008; Nincic and Datta, 2007: 242-4; Shapiro and Bloch-Elkon, 2005), whilst the majority of studies of congressional voting behaviour also conclude that partisan polarization has increased over that period (Fleisher et al, 2000; Kupchan and Trubowitz, 2007, 2010; McCormick, 2010: 484-7; McCormick et al, 1997; McCormick and Wittkopf, 1990; Prins and Marshall, 2001; Trubowitz and Mellow, 2011). The majority view, then, is that partisan polarization has increasingly affected foreign policy-making and that, just as in domestic politics, the moderate centre ground has been abandoned. In its most stark formulation (Kupchan and Trubowitz, 2007) this argument asserts that bipartisanship in foreign policy is dead. Accordingly, we refer to this position as the 'dead centre' thesis.

Recently, however, a small but growing critique of this view has begun to emerge. In a series of articles examining elite-level survey data, Busby and his co-authors argue that, despite deep partisan rifts on certain issues, the gulf between the parties is not as wide as has been claimed and that in many key areas there is considerable bipartisan agreement (Busby and Monten, 2008; Busby et al, 2012, 2013). Whereas Busby et al seek to qualify the claim of increased polarization, Chaudoin, Milner and Tingley (2010) reject the argument completely. They use a range of measures, including survey data, levels of congressional gridlock and cosponsorship of bills in Congress to support their claim, but the most striking part of their argument is their analysis of voting patterns in Congress. Stripping out amendment and procedural votes on the grounds that they are typically of little significance yet tend to display high levels of polarization, they find that the remaining 'substantive' votes show no increase in polarization since the early 1970s. Polarization is, in other words, a statistical artefact. $^{2}$ Their overall conclusion is unequivocal: 'bipartisanship on foreign policy has not 
steadily declined since the Vietnam war' (Chaudoin et al, 2010: 76). Following Chaudoin and his co-authors, we refer to this as the 'holding centre' thesis.

The present paper brings three new elements to bear on this important dispute. First, it re-evaluates the longitudinal congressional roll call data hitherto presented by scholars. We focus on congressional roll calls because they are a standard indicator in polarization studies and thus provide the widest base for comparison with the existing literature, and because the analysis and interpretation of roll call data is the point of starkest difference and greatest contention in the dead centre $v s$ holding centre dispute. This paper differs from extant ones by utilizing the broadest range of roll call indicators to provide a more comprehensive test of the dead and holding centre theses. Slicing the data in different ways reveals a fresh perspective, suggesting strongly that neither thesis captures the trends in polarization prior to 2004 . Second, the paper brings new congressional roll call data to the table from the 2004-13 period. Most analyses confirm that contemporary politics is more polarized than ever (Voteview.com, 2014; Gallup, 2012), but no scholars have systematically interrogated foreign and defence votes during the last decade. Any conclusions about contemporary foreign policy polarization have thus been largely impressionistic, unsupported by hard data and robust analysis. We find that, as per the pre-2004 period, it is impossible to characterize over-time change in the later period as indicative of either polarization or bipartisanship. Even this short time frame is defined instead by considerable variation. Third, whereas studies to this point have concentrated on trends over time, we also utilize a static measure of polarization to determine whether Congress is polarized or not at any particular point in time. This indicator confirms the conclusion that it is inappropriate to characterize congressional voting on foreign and national security issues since 1970 as either partisan or bipartisan. The evidence supports a much more complex and nuanced conclusion than that presented in the dead centre and holding centre theses. The next section presents the data and indicators and 
explains how the derived figures were constructed. The final section discusses the importance of the findings, the study's limitations and possible extensions for future research.

\section{METHODOLOGY AND DATA}

This paper focuses on the period 1970 to 2012. Kupchan and Trubowitz (2007) argue that bipartisanship on foreign policy began to erode in the early 1970s (as a consequence of the ideological conflicts engendered by the Vietnam War), was in serious disrepair at the Cold War's end, and fully dismantled during George W. Bush's presidency. To support this case, they present congressional roll call data from 1970 to 2004. Chaudoin and colleagues (2010: 88-89) utilize roll call data from the same period in their statistical analysis of the over-time trends. ${ }^{3}$ This paper follows the lead of the proponents of the dead centre and holding centre theses and begins its trend analysis in 1970 but it extends the end date to 2012, and in doing so provides the most up-to-date analysis of trends hitherto presented.

As well as extending the time frame of the analysis, this paper extends the range of indicators used to measure polarization in congressional roll call votes. The first indicator is designed to capture Congressional Quarterly's standard definition of a party unity vote, which has been widely adopted as a key measure of legislative polarization. Using Poole and Rosenthal's NOMINATE data, the indicator measures the percentage of time in each year that a majority of voting Democrats opposed a majority of voting Republicans on foreign policy votes. ${ }^{4}$ Tariffs and trade regulation issues are included as foreign policy votes. ${ }^{5}$ Procedural votes are excluded from the analysis, but amendment votes included. ${ }^{6}$

The second indicator seeks to capture the trends in foreign policy polarization by comparing the level of party unity votes on foreign policy relative to domestic policy. In 'The 
Two Presidencies', Wildavsky's key point was that, as a result of inherent institutional advantages and congressional deference, 'since World War II presidents have had much greater success in controlling the nation's defense and foreign policies than in dominating its domestic policies' (Wildavsky, 1966: 7). By extension, Congress can be said to be polarizing on foreign policy issues when party unity on them is increasing relative to domestic policy, since this indicates that politics does not stop at the water's edge and conflict on foreign policy mirrors that on domestic issues.

To determine whether the over-time changes in the direction of the first two indicators of polarization are not simply random, the party unity scores are regressed on multiple polynomial functions of time (for example, time, time squared, time cubed and so on). The fitted values from the best specifications are plotted to identify the time series trends in the data.

While the first two indicators of polarization include all votes except procedural ones, these votes vary in importance from the significant to the trivial. A key aspect of the dispute between Kupchan and Trubowitz and Chaudoin and his co-authors is the methodological question of how best to include in the analysis only substantive votes while excluding nonsubstantive ones. Our approach is to include only those votes on which the president takes a position, since it is generally acknowledged that presidents do not take positions on trivial issues (King and Ragsdale, 1998: 49). ${ }^{7}$ The second two measures do just this. The analytical procedure replicates that for the first two measures, exploring both time trends and the yearly differences between levels of party unity on foreign policy and domestic policy votes, but restricts the analysis to Congressional Quarterly's presidential position votes.

One potential criticism of these two sets of indicators of polarization is that party unity votes require only half of both parties to vote against each other, and do not distinguish 
such narrow votes from those where inter-party opposition is more extensive. In an attempt to measure polarization more finely, the final longitudinal indicator calculates the relative degree of support a president is able to garner from his own party in the House relative to the opposition party when he takes a public stand on an issue/vote. ${ }^{8}$

So far, we have discussed trends in party unity votes and presidential support. Such trends capture the idea of polarization as a process, but it is also necessary to think about it as a state (DiMaggio et al, 1996: 693). In other words, Congress may be becoming more or less polarized over time but it may also be polarized or not at a specific point in time. Congress can be polarized on both dimensions at once, on neither dimension, or on one dimension but not the other.

Testing whether Congress is polarized or not at a specific point in time is more problematic than testing its properties over time. A key difficulty is identifying an objective level above or below which Congress can be said to be polarized or not (Hetherington, 2009). Is Congress polarized if majorities in each party vote against each other half the time? Taking a midpoint of 50 percent seems as arbitrary as 40 or 60 , or any other figure. Even comparing a year or period average against, say, the post-war average offers little analytical leverage. It enables us to say that party unity in one year is greater or less than the average, but not whether Congress is polarized or not. Utilizing the logic of Wildavsky's two presidencies thesis once more, we suggest that an effective static indicator of polarization in foreign policy can be constructed by comparing the level of party unity in foreign policy relative to domestic policy in each year separately. Assuming as per all the literature on the topic that Congress is polarized on domestic issues, it follows that Congress can be said to be polarized (as distinct from polarizing) on foreign policy issues when party unity on them is statistically indistinguishable from party unity on domestic issues, and not polarized when the parties are statistically more united on domestic issues than on foreign ones. A simple $t$ test for each year 
tests the null hypothesis that there is no difference between the two policy areas. The red dots on the difference line in figure 1 identify years in which partisanship on foreign policy is statistically indistinguishable from that on domestic policy (the null cannot be rejected) and Congress is inferred to be polarized. The black dots identify years with significant differences (the null is rejected) and Congress is inferred not to be polarized. Figure 2 restricts the analysis to party unity scores on presidential position votes.

Congress can also be said to be polarized, we suggest, when the president enjoys a statistically significant higher level of support on foreign policy issues from his own party compared to the opposition. A t-test interrogates the null hypothesis that there is no partisan difference in support. Red dots on the difference line in figure 3 highlight years in which the difference is statistically significant (the null is rejected) and Congress is inferred to be polarized. Black dots represent non-polarized years.

\section{DATA ANALYSIS I}

The upper line in figure 1 plots party unity scores on foreign policy votes from 1970 to 2012 - that is, the yearly proportion of foreign policy votes on which majorities in the two House parties voted against each other. Simply eyeballing the line suggests a considerable degree of fluctuation across the period. The proportion of party unity votes on foreign policy increased in the 1970s and 1980s before reaching a post-war high in 1995, when the two parties voted against one other almost three-quarters of the time. Partisanship then declined, and by the first two years of George W. Bush's presidency less than three in ten foreign policy votes were along party lines. The rest of the Bush years and Obama's first term appear to be characterized by further flux. 
While this initial interpretation does not suggest strong support for either the dead centre or holding centre thesis, eyeballing the data cannot provide more than an impressionistic account of polarization. To be more certain, we regress party unity on multiple polynomial functions of time and fit the best specified model (regressions not shown but available on request). The model is statistically significant and has an adjusted $\mathrm{R}^{2}$ of .41 , and the fitted values tell the same story of rise, decline and flux. The trend does not offer any more support to the dead centre or holding centre thesis than eyeballing the data.

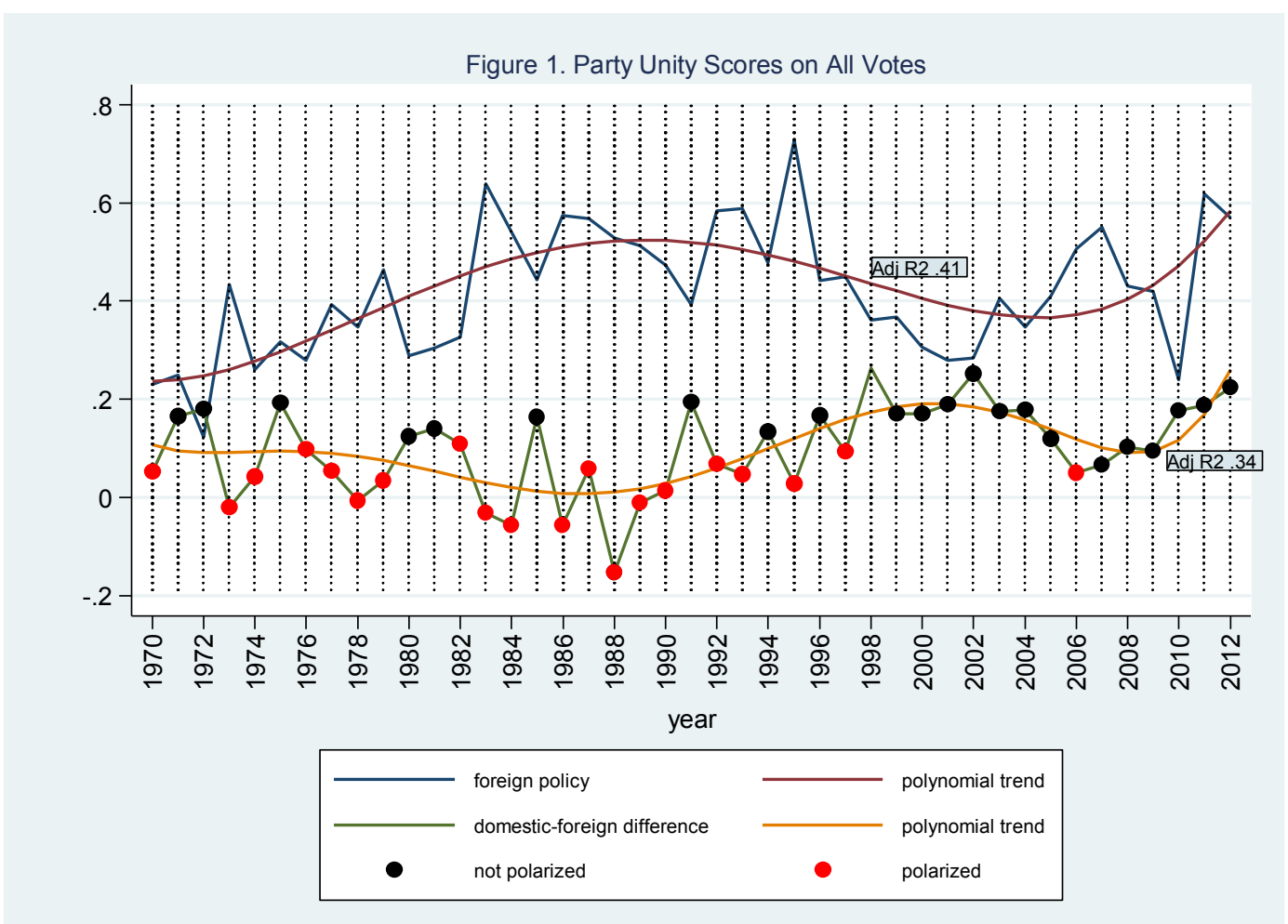

The second indicator of the over-time trend in polarization compares the level of party unity in foreign policy to unity in domestic matters. Recall that the polarization hypothesis is supported by a narrowing of the difference between the two policy areas, because foreign policymaking is inferred to be polarizing when party unity on it matches or exceeds that in domestic matters. The difference line in figure 1 demonstrates marked year-on-year 
fluctuations over time. ${ }^{9}$ Our focus here is the direction of the underlying trend. To establish this trend statistically, we regress the year differences on multiple polynomial functions of time. The fitted model is statistically significant and has an adjusted $\mathrm{R}^{2}$ of .34 . Party unity on foreign policy grew to match unity on domestic affairs during the 1970s and 1980s, but the trend reversed in the 1990 s as inter-party conflict on foreign matters declined relative to domestic ones. The presidency of George W. Bush ended the revival of bipartisanship in foreign policy, as inter-party conflict increasingly matched that in domestic policy. Thus far, the story told by figure 1's difference line replicates that told by the foreign policy line. However, the lines tell opposing tales about the Obama presidency. On the one hand, the foreign policy line shows party unity voting on foreign affairs increased. On the other, the difference line shows party unity on domestic affairs increased relative to foreign affairs. The first measure supports the polarization hypothesis while the second challenges it. The conflicting stories emphasize that it is unwise to make grand claims about the centre dying or holding. While the post-1970 trends identified by the first two measures are not random, neither do they offer compelling evidence for either theoretical perspective. 


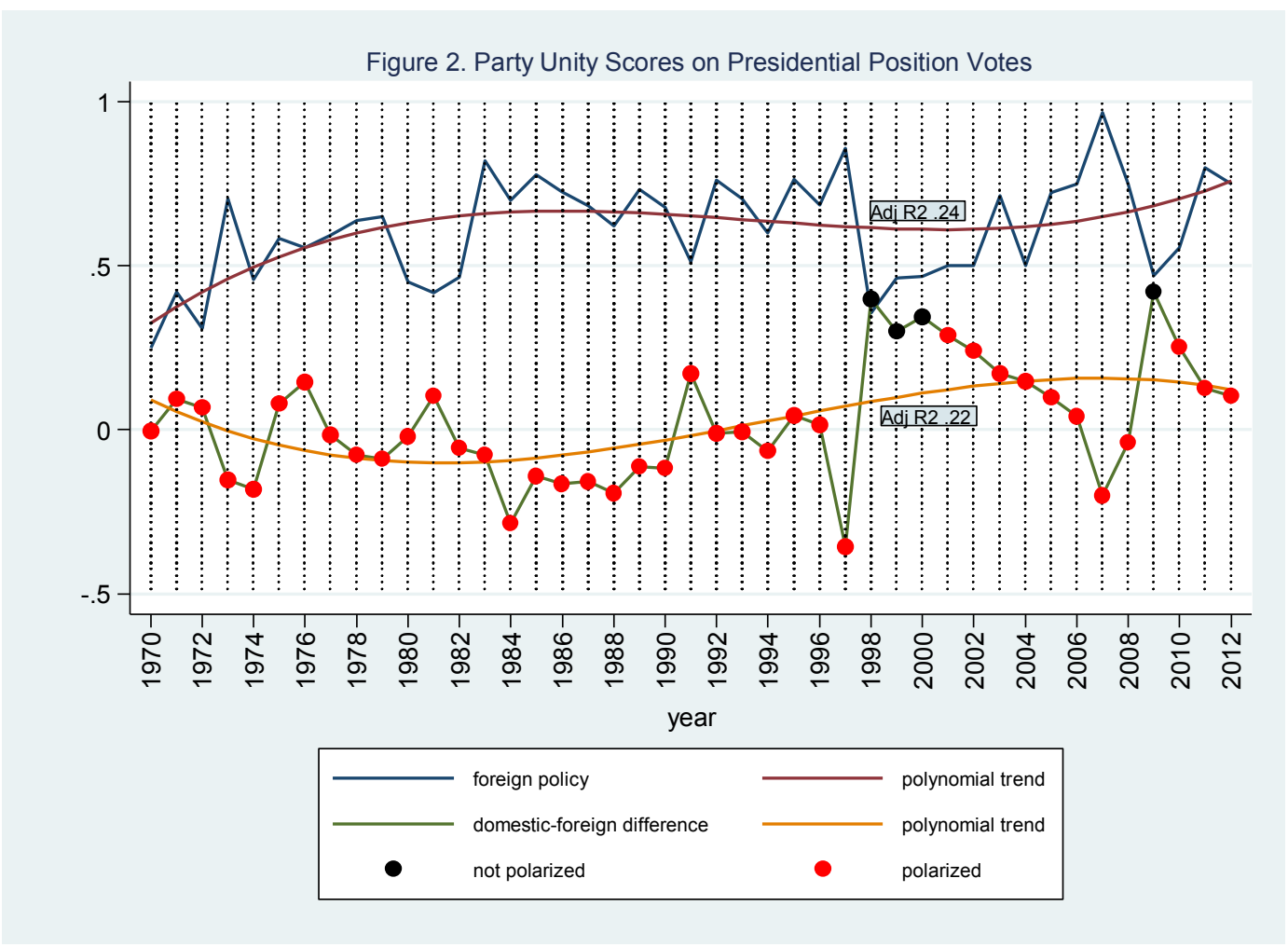

Do the second two measures offer clearer support for one of the theses? Unlike the first two measures, the second two restrict House roll call votes to those on which the president took a clear public position. The upper line in figure 2 plots average yearly party unity scores on foreign policy votes on which the president took a position, and the polynomial trend fits the best specified model derived from regressing party unity on a series of multiple year trends. The trend is towards increased party unity scores in the 1970s, which level off in the 1980s, dip in the 1990s and move gently upward in the new millennium. These trends are similar but less pronounced than those in the all votes model graphed in figure 1. Indeed, the low $\mathrm{R}^{2}(.24$, compared to .41 in the all votes model) is in part a function of this flatter trend, but it is also a function of the greater variation around the trend, which in turn generates a larger residual sum of the squares. This indicator, like the first, does not provide convincing evidence of a trend towards polarization or bipartisanship. 
The lower line in figure 2 plots the difference between the party unity scores on foreign and domestic votes on which the president took a position. Note that many of the data points are below zero, especially in the first half of the series. A negative score means that party unity is higher, and therefore more polarized, on foreign votes than domestic ones. In the 1970 s, foreign policy voting was more partisan, and increasingly more partisan, than domestic policy voting. The difference declined gradually in the $1980 \mathrm{~s}$, but the parties continued to vote against each other more often on foreign issues than domestic ones. Partisanship on foreign issues fell back towards the levels of partisanship on domestic issues in the 1990s. The new century witnessed a continuation of this trend, although it turned once again back towards partisanship in the late Bush and Obama presidencies. The overall trend, however, is quite flat and the variation around the trend high. As per the foreign policy party unity trend, this generates a low $\mathrm{R}^{2}(.22)$. Restricting the analysis to presidential position votes does not thus provide succour to either the dead or holding centre thesis.

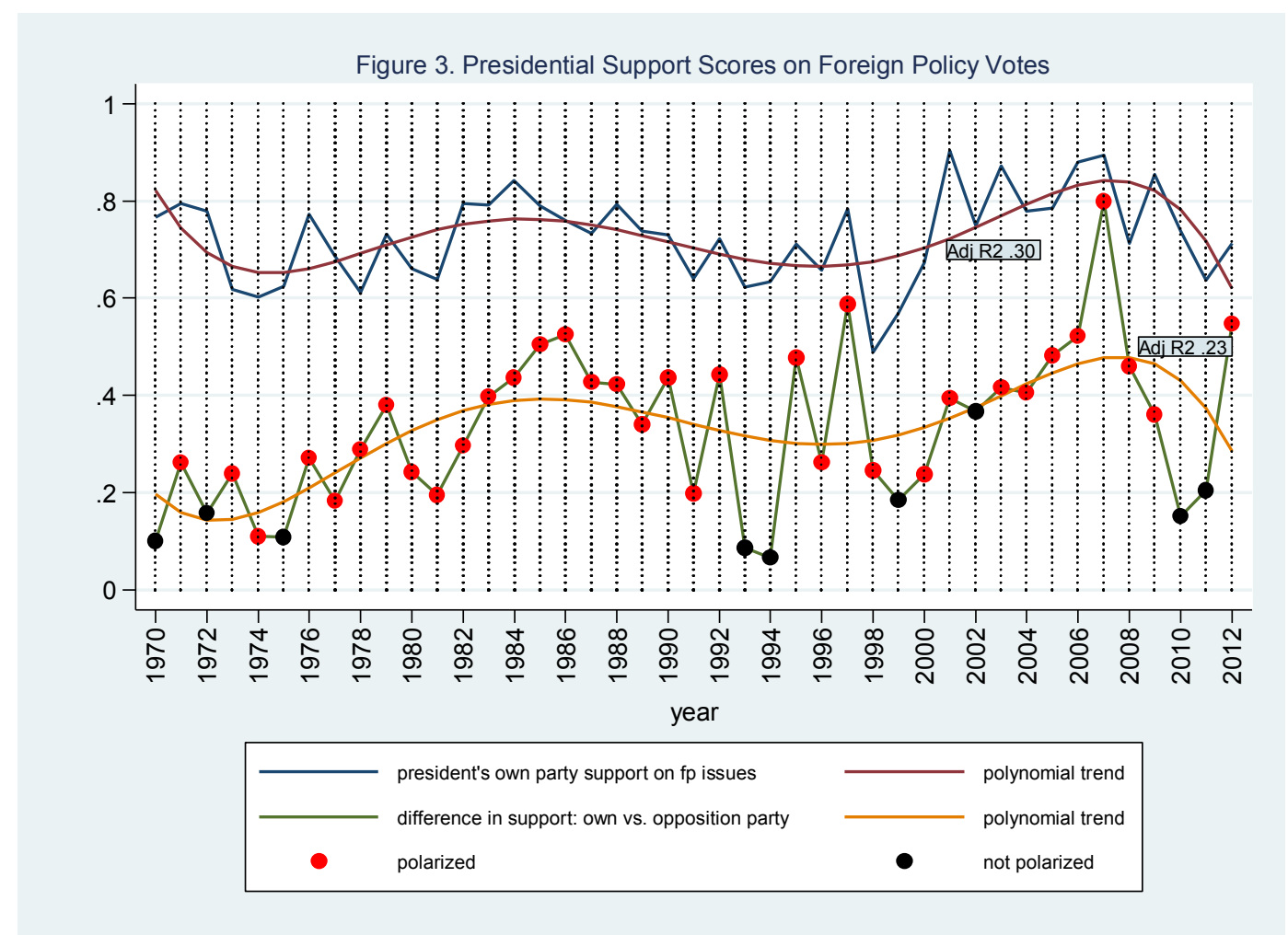


As noted in the methodology section, the logic of polarization suggests that presidents' own-party and opposition-party support should be diverging over time on foreign policy issues. The final two indicators plotted in figure 3 report presidents' own-party support on votes on which they took a public position and, more crucially, the average yearly difference in the level of support between presidents' own party and the opposition party. The trends overlaying the indicators are again derived by regressing the difference on multiple polynomial functions of time. Unlike the difference plots in figures 1 and 2 , where a narrowing of the difference between foreign and domestic policy was interpreted as evidence in favour of the polarization hypothesis, an increase in the difference line in figure 3 is suggestive of polarization.

The data show that presidents enjoyed increasingly higher levels of support from their own party relative to the opposition from 1970 to the mid 1980s, but this trend reversed in the late 1980s and early 1990s as the inter-party difference declined. The trend towards greater agreement on foreign policy issues ended with the Republican takeover of the House in the November 1994 elections. The re-assertion of inter-party differences that began in the $104^{\text {th }}$ Congress continued through most of the remainder of Clinton's presidency and though the majority of Bush II's. Contrary to the rally effects hypothesis, the war on terror did not generate a rush of support for the president's foreign policy positions, particularly among opposition members. The incremental ending of the conflict and the election of Barack Obama at the decade's end coincided with a renewed bout of opposition support for the president and a slight decline in support from his own party. Note again, however, the low $\mathrm{R}^{2}$ (.23) on the difference line's polynomial trend, which is a consequence of large amounts of unaccounted for variance around the trend. This, plus the up-down-up-down variation in support for presidents' foreign policy positions across four post-Vietnam decades, does not offer support to either the dead centre or holding centre thesis. That the data do not tell a neat 
tale of bipartisanship or polarization is itself an important corrective to the overly straightforward stories posited in the existing literature.

\section{DATA ANALYSIS II}

The analysis so far has focussed on over-time trends, and failed to find sufficient evidence to support either the dead centre or holding centre thesis. Yet polarization can be conceived of as a state as well as a process (DiMaggio et al, 1996: 693). We address the key problem of determining whether Congress is polarized on foreign issues at a point in time by testing whether the two political parties are statistically more united against each other on foreign than domestic policy (on both all votes and those where the president staked out a position) and whether the president enjoys statistically greater support for his foreign policy positions from his own party than from the opposition. As described in the methods section, a simple $t$ test scrutinizes the null hypothesis that there is no statistically significant difference for each year under consideration.

Between 1970 and 2012, majorities of the two parties aligned against each other 43.6 percent of the time on all foreign policy votes and 53.1 percent of the time on domestic votes, a statistically significant difference (chi2 $=144.3 ; \mathrm{p}=.00$ ). Considering the period as a whole thus offers some tentative support to the holding centre thesis, because partisanship on domestic policy is statistically higher than on foreign affairs. But this period average may mask important yearly differences. The year-on-year $t$ test analysis (reported in figure 1) suggests that the House of Representatives was polarized on foreign policy issues —or, put differently, that party unity on foreign policy at least matched that on domestic policy_about two thirds of the time from 1970 to 1990 . Scores below zero represent years when party unity scores are actually higher on foreign than domestic issues. The final decade of the twentieth 
century saw a decrease in the number of polarized years, with polarized and non-polarized years occurring as often as each other. The new century has continued this trend away from polarization. In only one (2006) of the last dozen years under consideration has party unity on foreign issues matched that on domestic ones.

However, the party unity scores on votes on which the president took a public position tell a different story (figure 2). On presidential position votes over the whole period, majorities in each party voted against each other on 62.4 percent of domestic policy roll calls between 1970 and 2012 and on 64.1 percent of foreign policy votes, a statistically insignificant difference ( $\mathrm{chi} 2=.9 ; \mathrm{p}=.34)$. Unlike on all votes, where House members are statistically more united against each other on domestic issues than foreign ones, inter-party conflict on the hot-button foreign policy issues on which presidents take positions at least matched that on the big domestic issues in every year but four, a finding which supports the dead centre thesis.

This story is supported by the final indicator, which examines presidential support scores on foreign policy votes on which the president staked a public position (figure 3). Over the whole period, presidents' support from their own party averaged 72.8 percent compared to 41.4 percent from the opposition party, a statistically significant difference $(p=.00)$. The red dots represent years in which the average level of own-party support was higher, to a statistically significant degree, than the opposition's. Polarized years, represented by the red dots, constitute a large majority of the series.

In sum, when thinking about polarization as a state rather than a process, two indicators support the dead centre thesis and one supports the holding centre thesis. Congress has been consistently polarized on the big foreign policy votes on which the president goes 
public. It is much less polarized when all votes are considered, and the new century in particular can be characterized as non-polarized.

\section{DISCUSSION}

As we have seen, existing studies of partisan polarization and US foreign policy fall into two camps: a majority who argue that US foreign policy-making has become increasingly polarized and a minority who argue that bipartisanship remains the norm. We have termed these two positions the dead centre and the holding centre theses, respectively. Our analysis has sought to shed new light on this debate through a re-examination of foreign policy voting in the House of Representatives, using a more extensive range of indicators than previous analyses, extending the longitudinal analysis up to the end of president Obama's first term, and including a static indicator of polarization.

That analysis presents a picture that is problematic for both sides of the existing debate and for those who like simple clear-cut answers. The polynomial trend lines for all indicators fail to conform either to the increasing polarization trend identified by the dead centre thesis or to the unchanging or declining trend identified by the holding centre argument. The analyses of party unity using all votes bar procedural ones (figure 1) on the one hand and only presidential position votes on the other (figure 2) both tell a similar story of an initial increase in polarization through the 1970s and into the 1980s, a levelling off and subsequent decline in polarization from the late 1980s, followed by another upturn in polarization from the mid 2000s. The analysis of presidential support scores in figure 3 demonstrates a similarly fluctuating up-down-up-down pattern of polarization. 
The data do not, therefore, accord with the argument of the proponents of either thesis. On the one hand and contra the holding centre argument, the trend data indicate that that there was an increase in polarization for the best part of two decades. Nor can this increase be explained away, as Chaudoin et al have argued, by the bias caused by the inclusion of non-substantive votes in the data. When we run the analysis using only presidential position votes we find the same pattern that we find in the all-vote data. On the other hand, while the trend of increasing polarization from 1970 to 1990 provides support for the dead centre thesis, the subsequent decline in polarization and the overall cyclical nature of the polarization trends challenge the dead centre argument. Dead centre advocates might seek to argue that the decline in polarization between 1990 and the mid-2000s was simply a shortterm 'blip' and that the upward trend has subsequently restored itself. Only time will tell whether that is in fact the case but, on its face, it is difficult to argue that a period of 15 years out of a total period under scrutiny of some 42 years, representing more than one-third of the total period under examination, constitutes a blip.

The data analysis examining foreign policy polarization at specific points in time returns similarly complex and contradictory results. Both of the analyses utilizing presidential position votes demonstrate that House voting on foreign policy issues on which the president has taken a stand has been polarized for a clear majority of the time since 1970 . The claim that bipartisanship remains the norm in foreign policy making is thus confounded, at least as far as House voting is concerned. Whilst the static data on presidential position voting support the claim that polarization has become the norm, the analysis of all votes in figure 1 flatly contradicts that argument with polarization becoming the exception rather than the rule since 2000.

In conclusion, the binary choice — dead centre or holding centre — presented in the literature on foreign policy polarization is too simplistically drawn. It is tempting to seek to 
divide history, even the most recent history, into neatly identifiable periods characterized by certain physiognomies, but no such taxonomy is possible in the present case. Congress is not polarized or polarizing on foreign policy issues; nor is it not polarized or becoming less polarized. In many ways, this is rather an unsatisfying conclusion, but it is one the evidence points towards strongly. It confronts both the conventional wisdom (the dead centre thesis) and the key challenge to the conventional wisdom (the holding centre thesis).

What remains, therefore, is the problem of accounting for this rather complex and, at least in the case of the static data, apparently contradictory, set of results. Advocates of the dead centre hypothesis have offered a variety of arguments to explain the alleged increase in foreign policy polarization. The most prominent amongst them attribute polarization to the impact of the Vietnam War on the policy preferences of members of the two parties (Kupchan and Trubowitz, 2007; Nincic and Datta, 2007; Shapiro and Bloch-Elkon, 2005), the effects of the end of the Cold War (Kupchan and Trubowitz, 2007; Marshall and Prins, 2002), changes in the foreign policy issue agenda to include more economic and 'intermestic' issues (Prins and Marshall, 2001; McCormick and Wittkkopf, 1992), and the broad changes in partisan ideology and institutional procedures which are held to be responsible for the general increase in partisan polarization in Congress since the 1970s (Fleisher and Bond, 2004; Jacobson, 2000; McCarty et al, 2006; Theriault, 2008). Whichever individual explanation or combination of these explanations is preferred, however, all are premised on an ongoing and/or permanent change in the independent variable(s) which, in turn, produces a similarly permanent and ongoing change in the dependent polarization variable as a result. They are thus unable to explain the cyclical trend in polarization that we have found.

It does not follow that some or all of these factors are not necessary to an explanation of the current state of affairs - most of our indicators do suggest that partisan polarization did increase from the early 1970s until around 1990 — but they are not sufficient in themselves to 
account for developments since the mid-1990s. An adequate account of those recent developments needs to incorporate either (1) new independent variables that fluctuate over time in a fashion that correlates with changing patterns of polarization or (2) intervening variables that minimize or reinforce the effects of the variables that are currently identified as causes of foreign policy polarization. Possible candidates for these roles might include changing patterns of economic growth (Trubowitz and Mellow, 2011), the existence or nonexistence of divided government, the differential impact of a changing issue agenda and the partisan affiliation of the president. What we can be certain of, however, is that much work remains to be done before we have a satisfactory account of the effects of partisan polarization on the making of American foreign policy. 


\section{Bibliography}

Abramowitz, A.I. and Saunders K.L. (2008) Is polarization a myth? The Journal of Politics 70 (2): 542-555

Beckman, M.N. and Kumar, V. (2011) Opportunism in polarization: Presidential success in key Senate votes, 1953-2008. Presidential Studies Quarterly 41 (3): 488-503

Busby, J.W. and Monten J. (2008) Without Heirs? Assessing the decline of establishment internationalism in U.S. foreign policy. Perspectives on Politics 6 (3): 451-472

Busby, J.W. and Monten J. (2012) Republican elites and foreign policy attitudes. Political Science Quarterly 127 (1): 105-42

Busby, J.W., Monten J., Tama, J., and Imboden, W. (2012) American foreign policy is already post-partisan: Why politics does stop at the water's edge. Foreign Affairs 30 May 2012, http://www.foreignaffairs.com/articles/137669/joshua-w-busby-jonathan-monten-andwilliam-inboden/american-foreign-policy-is-already-post-partisan, accessed 19 June 2014 Busby, Joshua W., Jonathan Monten, Jordan Tama and William Imboden (2013) Congress Is Already Post-Partisan: Agreement Across the Aisle on U.S. Foreign Policy. Foreign Affairs 28 January, http://www.foreignaffairs.com/articles/138791/joshua-w-busby-jonathanmonten-jordan-tama-and-william-inboden/congress-is-already-post-partisan, accessed 19 June 2014

Carmines, E.G. and Stimson, J. A. (1989) Issue evolution: Race and the transformation of American politics. Princeton: Princeton University Press

Carson, J., Crespin, M.H., Finocchiaro, C.J. and Rohde, D.W. (2007) Redistricting and party polarization in the US House of Representatives. American Politics Research 35: 878-904 
Chaudoin, S., Milner, H.V. and Tingley, D.H. (2010) The center still holds: Liberal internationalism survives. International Security 35 (1): 75-94

Cox, G.W. and McCubbins, M.D. (2005) Setting the Agenda: Responsible party government in the US House of Representatives. New York: Cambridge University Press

DiMaggio, P., Evans, J. and Bryson, B. (1996) Have Americans' social attitudes become more polarized? American Journal of Sociology 102 (3): 690-755

Fiorina, M.P., Abrams, S.A. and Pope, J.C. (2006) Culture war? The myth of a polarized America. New York: Pearson Longman

Fleisher, R. and Bond, J.R. (2000) Partisanship and the President's quest for votes on the floor of Congress. In: Fleisher, R. and Bond, J.R. (eds), Polarized politics: Congress and the president in a partisan era. Washington DC: CQ Press, pp. 154-85.

Fleisher, R. and Bond, J.R. (2004) The shrinking middle in the US Congress. British Journal of Political Science 34 (3): 429-451

Fleisher, R., Bond, J.R., Krutz, G.S. and Hanna, S. (2000) The demise of the two presidencies. American Politics Quarterly 28 (1): 3-25

Gallup. (2012) Obama ratings historically polarized. 27 January, http://www.gallup.com/poll/152222/obama-ratings-historically-polarized.aspx, accessed 14 December 2012

Hetherington, M. J. (2001) Resurgent mass partisanship: The role of elite polarization. American Political Science Review 95 (3): 619-631

Hetherington, M.J. (2009) Putting polarization in perspective. British Journal of Political Science 39 (2): 413-448 
Jacobson, G.C. (2010) A divider, not a uniter: George W. Bush and the American people. New York: Pearson Longman

King, G. and Ragsdale, L. (1988). The elusive executive: Discovering statistical patterns in the presidency. Washington, DC: Congressional Quarterly Press

Kupchan, C.A. and Trubowitz, P.L. (2007) Dead center: The demise of liberal internationalism. International Security 32 (2): 7-44

Kupchan, C.A. and Trubowitz, P.L. (2010) The illusion of liberal internationalism's revival. International Security 35 (1): 95-109

Layman, G.C., Carsy, T.M. and Horowitz, J.M. (2006) Party polarization in American politics: Characteristics, causes and consequences. Annual Review of Political Science 9 (1): $83-110$

Lee, F.E. (2008) Dividers, not uniters: Presidential leadership and Senate partisanship, 9812004. Journal of Politics 70 (4): 914-928

Levendusky, M. (2009) The partisan sort: How liberals became Democrats and conservatives became Republicans. Chicago: University of Chicago Press

Marshall, B.W. and Prins, B.C. (2002) The pendulum of congressional power: Agenda change, partisanship and the demise of the post-World War Two foreign policy consensus. Congress and the Presidency 29 (2): 195-212

McCarty, N., Poole, K.T. and Rosenthal, H. (2006) Polarized America: The dance of ideology and unequal riches. Cambridge: MIT Press

McClosky, H., Hoffman, P.J. and O’Hara, R. (1960) Issue conflict and consensus among party leaders and followers. American Political Science Review 54 (2): 406-27 
McCormick J.M. and Wittkopf, E.R. (1990) Bipartisanship, partisanship, and ideology in congressional-executive foreign policy relations, 1947-1988. Journal of Politics, 52 (4): $1077-1100$

McCormick J.M. and Wittkopf, E.R. (1992) At the water's edge: The effects of party, ideology and issues on congressional foreign policy voting, 1947-1988. American Politics Quarterly 20 (1): 26-53

McCormick J.M., Wittkopf, E.R and Danna, D.M (1997) Politics and bipartisanship at the water's edge: A note on Bush and Clinton. Polity 30 (1): 133-149

Meernik, J. (1993) Presidential support in Congress: Conflict and consensus on foreign and defense policy. Journal of Politics 55 (3): 569-87

Newman, B. and Siegle, E. (2010) The polarized presidency: Depth and breadth of public partisanship. Presidential Studies Quarterly 40 (2): 342-63

Nincic, M. (2008) External affairs and the electoral connection. In: Wittkopf, E.R. and McCormick, J.M. (eds) The domestic sources of American foreign policy 5th ed. Rowman and Littlefield, pp. 125-40

Nincic, M. and Datta, M.N. (2007) Of paradise, power and pachyderms. Political Science Quarterly 122 (2): 239-56

Prins, B.C. and Marshall, B.W. (2001) Congressional support of the president: A comparison of foreign, defense and domestic policy decision making during and after the Cold War. Presidential Studies Quarterly 31 (4): 660-678

Rohde, D.W. (1991) Parties and leaders in the post-reform House. Chicago: University of Chicago Press 
Schraufnagel, S. and Shellman, S.M. (2001) The two presidencies, 1994-1998: A replication and extension. Presidential Studies Quarterly 31 (4), 699-707

Shapiro, R. and Bloch-Elkon, Y. (2005) 'Partisan conflict, public opinion, and U.S. foreign policy. Paper presented at the Inequality \& Social Policy Seminar, John F. Kennedy School of Government, Harvard University, Cambridge, Mass., 12 December http://www.hks.harvard.edu/inequality/Seminar/Papers/Shapiro05.pdf, accessed 25 October 2012

Sinclair, B. (2006) Party wars: Polarization and the politics of national policy-making. Norman: University of Oklahoma Press.

Stonecash, J.M., Brewer, D. and Mariani, M.D. (2002) Diverging parties: Social change, realignment and party polarization. Boulder: Westview

Theriault, S.M. (2008) Party polarization in Congress. Cambridge: Cambridge University Press

Trubowitz, P. and Mellow, N. (2011) Foreign policy, bipartisanship and the paradox of postSeptember 11 America. International Politics 48 (2/3): 164-87

Voteview.com (2012) An update on political polarization (through 2011). 30 January, http://voteview.com/blog/?p=284, accessed 12 December 2012

Voteview.com (2014) The polarization of the congressional parties. 19 January, http://voteview.com/political_polarization.asp, accessed 17 February 2014

Wildavsky, A. (1966) The two presidencies. Trans-Action 4, (December): 7-14

Wittkopf, Eugene R. (1986) On the Foreign Policy Beliefs of the American People: A Critique and Some Evidence, International Studies Quarterly 30: 425-445 
Wittkopf, Eugene R. (1990) Faces of Internationalism: Public Opinion and American

\author{
Foreign Policy Durham, NC: Duke University Press
}

Wroe, A., Ashbee, E., and Gosling, A. (2014) The culture war and issue salience: An analysis of American sentiment on traditional moral issues. Journal of American Studies 48 (2): 595-

612

\footnotetext{
${ }^{1}$ The question of whether partisan polarization has also come to characterize the behaviour of ordinary voters is more contested. See, for example, Abramowitz and Saunders (2008); Fiorina et al (2006); Layman et al (2006); Wroe et al, (2014).

${ }^{2}$ Kupchan and Trubowitz (2010: 100-1, and private correspondence with the authors) respond that Chaudoin et al are mistaken in assuming that they do not exclude procedural votes. Procedural votes were excluded (identified by Clausen's sixth category in his issue typology). Indeed, Kupchan and Trubowitz suggest, it is Chaudoin et al who are guilty of methodological inexactitude, because they unnecessarily exclude at least some policy-relevant amendment votes.

${ }^{3}$ Although they eyeball data back to 1953.

${ }^{4}$ This indicator is effectively the antonym of Chaudoin et al's and Kupchan and Trubowitz's key measure, which calculates the percentage of time that a majority of Democrats voted with a majority of Republicans.

${ }^{5}$ These are identified as code 51 in voteview.com's 'issue code one' categorization. We follow Kupchan and Trubowitz in this regard (personal communication with authors).

${ }^{6}$ The excluded procedural votes are identified as code 6 in Clausen's issue categorization on VoteView.com. We excluded procedural votes but not amendments because the former do not generally deal with substantive issues, while a majority of the latter do (see Kupchan and Trubowitz, 2010: 100-1).

${ }^{7}$ Presidential position is widely used in analyses of executive-legislative relations. See, for example, Beckman and Kumar, 2011; Marshall and Prins, 2002; McCormick et al, 1997; Prins and Marshall, 2001; and Schraufnagel and Shellman, 2001. Research has demonstrated that party polarization in Congress increases when the president stakes a position on an issue, domestic or foreign (Lee, 2008). But this factor, as a constant, cannot explain the over-time fluctuations or foreign-domestic differences in polarization reported here.

${ }^{8}$ Inferring a trend towards polarization based only on an increase the president's own-party support could be misleading, because the president may also enjoy a simultaneous increase in support from the opposition party. It is therefore necessary to make the inter-party comparison.

${ }^{9}$ The red and black dots speak to the question of whether Congress is polarized at a particular point in time, which is addressed separately below.
} 